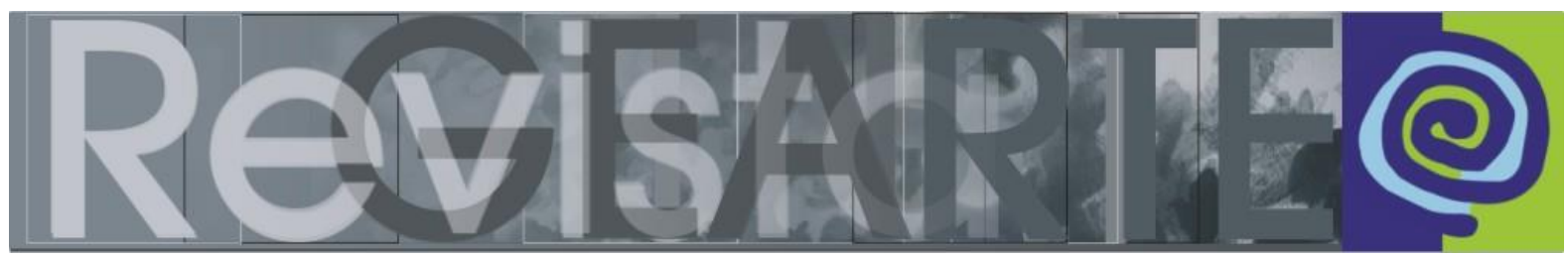

e-ISSN 2357-9854

\title{
Objeto étnico de pesquisa na comunidade para fomentar a aprendizagem interétnica
}

\author{
Ryan Shin (University of Arizona - UA, Tucson/Arizona, EUA)
}

\begin{abstract}
RESUMO - Objeto étnico de pesquisa na comunidade para fomentar a aprendizagem interétnica - Neste artigo, descrevo um projeto de educação sobre diversidade e justiça social, no qual meus alunos estagiários conduzem uma pesquisa de objetos étnicos em Tucson, Arizona. As referências conceituais utilizadas para envolver os alunos na pesquisa de objetos incluem três aportes teóricos inter-relacionados: a zona de contato (PRATT, 1991), objetos sociais (ENGESTRÖM, 2005), e estética relacional (BOURRIAUD, 2002). Através deste projeto, os estudantes se envolveram em diálogos e interações na comunidade com indivíduos e grupos de pessoas de diferentes origens étnicas e culturais, o que os ajudou a sair de suas próprias zonas de conforto. Os objetivos educacionais deste projeto incluem: superar a ansiedade social interétnica, desfazer equívocos e estereótipos, proporcionar a aprendizagem autorreflexiva e desenvolver empatia.
\end{abstract}

PALAVRAS-CHAVE

Pesquisa de objetos. Objetos sociais. Estética relacional. Empatia. Aprendizagem autorreflexiva.

ABSTRACT - Ethnic object research in the community to foster interethnic learning - In this paper, I describe a diversity and social justice education project, in which my pre-service students conduct an ethnic object research in Tucson, Arizona. The conceptual framework for engaging students with the object research draws from three interrelated theoretical backgrounds: the contact zone (PRATT, 1991), social objects (ENGESTRÖM, 2005), and Relational Aesthetics (BOURRIAUD, 2002). Through this project, students were engaged in dialogues and interaction with individuals and groups of people from different ethnic and cultural backgrounds in the community, which helped them break out of their own social comfort zones. The learning outcome of this project includes: overcoming interethnic social anxiety, challenging misconceptions and stereotypes, self-reflective learning, and developing empathy.

\section{KEYWORDS}

Object research. Social objects. Relational aesthetics. Empathy. Self-reflective learning.

\section{Introduction}

As a Korean immigrant to the U. S., my scholarly and personal interests have focused on migration, immigration, and diaspora of diverse ethnic groups in North America. Examining global and local changes that affect the lifestyle and culture of immigrant groups of people, I have cared about their vulnerability in face of changes in immigration status and policies, which affect their job security and educational opportunities for their children. Similarly, to the United States. Many large multicultural countries such as Brazil or the United States have a long history of immigration and emigration that includes peoples from Asia, Europe, Latin America, and other continents (WEJSA; LESSER, 2018). As of recently, more contentious issues and 
concerns about immigration in both Brazil and the United States have risen due to changes in government, leadership, and resulting policy changes. In this paper, rather than seeing cultural diversity as a social and political problem, I seek to recognize how migration promotes diversity in our communities. From the perspective of an art educator who is also an immigrant, I want to help my students develop skills to access cultural meaning. To that end, I developed the ethnic object research project as an assignment to my university students.

One of the main reasons of starting this project is that many groups of people, regardless of race, ethnicity, and cultural background, have limited experience in terms of interethnic and interracial communication. Educators and social scientists Patricia Gurin, Eric Dey, Sylvia Hurtado, and Gerald Gurin (2002) noted that attending an ethnically diverse public school or university does not necessarily guarantee meaningful interracial interaction, therefore they suggest that students engage with diverse others in deeper, more meaningful ways. The experience of my daughter attending a prestigious college in East Coast also echoes this concern because her limited experience engaging with diverse groups of people in a deep and more intimate level was in contrast with her high school experience in Arizona where she had friends from various ethnic backgrounds. This lack of communication and opportunities to meet among people of different ethnic and cultural groups was evident in my students' autobiography assignment during the first week of the course Diversity Issues in Art and Visual Culture Education. This personal narrative essay about their lives and the experiences that have shaped their views on race, ethnicity, culture, gender, etc. provided me with a wealth of information about my students' backgrounds, indicating a general lack of interethnic meeting and communication.

Another reason to develop this project is to facilitate that students hear the voices of minority-group members in their communities in order to provide authentic learning experiences and expand their understanding of others. This is especially true for white students or students from rural areas who tend to have a naïve conviction of the fairness and equality in American society. Many white and middle-class students have not had opportunities to realize what people of minority groups experience, such as stereotyping, prejudice and discrimination (RODENBORD; HUYNH, 2006). Below, 
I describe the ethnic object research project that allowed my pre-service students to be involved in dialogue with other ethnic groups who are mostly immigrants in Tucson, Arizona. I will also discuss this project as an example of developing intercultural and interethnic relationships and understanding through ethnic object research. I believe that this kind of project can be implemented in other communities where diverse immigrant ethnic groups form a multicultural community.

\section{Ethnic Object Research in the Community}

The conceptual framework for engaging students with object research in the community draws from three interrelated theoretical backgrounds: the contact zone (PRATT, 1991), social objects (ENGESTRÖM, 2005), and relational aesthetics (BOURRIAUD, 2002). These concepts put an emphasis on the object as the vehicle of intergroup learning and communication, which helps develop meaningful relationships and understanding between groups of people. Each concept highlights different aspects of intercultural learning. Contact zone (PRATT, 1991) focuses on making connections between two cultures, social objects (ENGESTRÖM, 2005) addresses interpersonal relationships facilitated by objects, and relational aesthetics (BOURRIAUD, 2002) stress creating social experiences among people. The goal of intercultural interaction and communication through ethnic objects are achieved by complementary interweaving of the three concepts.

Pratt's (1991) concept, "the contact zone", is very useful in understanding and analyzing an ethnic object that serves as a door to understanding a different culture and exploring how students become familiar with other cultures. According to Pratt, a contact zone refers to "social spaces where cultures meet, clash, and grapple with each other" (p. 34). Objects could serve as the potential contact zone through which students are exposed to other ethnic cultures, creating an intersection and interaction between different cultures. Students can recognize cultural differences while both learning different expressions and modes and gaining new knowledge, resulting in mutual understanding. Bolin and Blandy (2003) also notes the value associated with objects, acknowledging how mundane and everyday objects are worthy of study in art education. Exploring an ethnic object requires examining more than visual expressions and asks us to look at various forms of human life, such as folklore, music and dances, 
plays, customs, foods, as well as stories and experiences of the user. In particular, objects contain stories of immigration and the culture of people who immigrated to the U. S. with them, so their stories are revealed around objects, which reflect on their life and experiences before immigration (WITCOMB, 2012).

Engeström's (2005) term, social objects, offers why this project can facilitate intercultural interaction and communication. Engeström analyzed social networking to examine the reason of what contributes to socially active and engaging relationships and networks and emphasized the centrality of objects in building social relationships. His view on social relationships advise us that teachers should focus on what facilitates human connection, for which I used objects as a social engaging tool that contributes to starting and developing conversation between people (SIMON, 2010). Cultural theorist Kwame Appiah (2006), arguing for a cosmopolitan approach, addresses that we should be tolerant of and celebrate different ideas and conceptions of other groups or communities. To accomplish this, Appiah suggests conversation as a way of understanding and addressing problems and disagreements, or metaphors to get to know others. Conversation through objects develops connections and relationships between groups of people, as many of my students reported in their research experiences.

According to Bourriaud (2002), relational artists make art objects for social interaction and communication between artists and audience, often resulting in events and installation in which objects, images, and activities are designed for exploring interpersonal interaction. Even though students did not make or develop art objects or events, they were involved with an object-centered social interaction with the owners of the object. Through this process, students were able to explore objects from different cultural groups and develop understandings of each group based on their relationships with the objects' owners.

I asked students to identify an image, object, or cultural practice that was easily accessible or experienced in the community - such as toys, symbols, arts and crafts, decorative objects, or cultural performances - which were the product of ethnic groups of people different from them. They were asked to work outside class for about four weeks in the fall semester of 2009. They were instructed to ask someone from the 
ethnic group where the object came from to assist them in exploring the history and tradition of the object. In so doing, they were encouraged to explore its functions, usage, meanings, details, and availability, as well as its role to or significance in the culture of the studied people. I suggested that they carry a picture of the object of study with them during the research period and that they make contact with members of the ethnic group from which it originated. I also suggested that the students participated in an ethnic/cultural event or practice along with their interviewee(s) or observed everyday events, such as market shopping, social gatherings, sports, dances, games, or recreational plays.

Cultural anthropologist Marvin Harris' (1976) distinction between emic (describing a culture from the viewpoint of the people being studied) and etic (describing a culture from a researcher's or outsider's cultural viewpoint) contributed to the development of this project, serving as a conceptual foundation in researching ethnic objects. He advocated the emic approach, which is to value and acknowledge foremost the viewpoints of cultural insiders. In describing "informants' culture," a phrase borrowed from linguist Kenneth Pike's (1967) study of the sounds of languages, Harris warned of an outsider's objectification and categorization of the observation of a culture. When using the emic approach, the critical viewpoint of those being studied will need to be respected and represented to outsider members of the culture. In this project, students applied the emic approach to formulate open-ended questions and conduct participant observations and interviews to gain an in-depth understanding of the studied object and culture from the view of cultural insiders.

Students were invited to use any of the following questions as a focus of their exploration and research. These questions led them to conduct prior research online and encouraged them to develop their own questions for further inquiry.

What is it? Where is it from? Where do you see these objects in our community? What culture, ethnic group, or nationality does it represent? Is there any historical or contextual information related to the object? Where do people use it? What are its physical characteristics? Is it used in a cultural performance? What does the ethnic group from which it came say about the object? Is there any folklore related to it? Does it represent any religion or related belief system? Why do you think that the group uses or displays it? What does this tell us about the group in terms of identity, culture, and ethnicity? 
For this project, students had ample time for exploring their community to search for a range of objects, images, and cultural practices observable and visible, which have not drawn their attention before, being considered peripheral and marginal part of their community. My students were encouraged to take pictures of the object of their choice and search its meaning, identity, and expression, as well as its functions and role in the group. They interviewed the people who brought the objects with them from their native countries. For example, the objects representing the ethnic diversity of Tucson include objects from East and South Asia, Africa, Middle East, Latin America, Native American culture, and Europe.

\section{What Students Learned from Ethnic Object Research and Intercultural Meetings}

They are four themes emerging from students' ethnic object and art explorations: overcoming interethnic social anxiety; challenging misconceptions and stereotypes; self-reflective learning; and developing empathy.

\section{Overcoming Social Anxiety}

Anxiety and psychological fear of meeting others might be one of the most important factors that keeps one from developing meaningful relationships with diverse groups of people. Anxiety is a key predictor of avoidance for other groups (PLANT; BUTZ; TARTAKOVSKY, 2008). To some students, there was considerable trepidation in the beginning of their research. Some experienced anxiety and fear before contacting and meeting their interviewees. They reported that, at first, they were not comfortable asking questions about identity and ethnicity because they were fearful of bringing up "inappropriate" issues. However, the student reports and subsequent class discussions revealed that as time passed these individuals gained confidence and frequently came to realize that many people are very open and want to share their life stories and culture. My students argued that the reward is well worth the risk, and that developing a confidence in meeting groups of people outside of their comfort zone, can be a very positive learning opportunity. This also reiterated the value many put on the study of the arts and cultural objects (CHALMERS, 1996) as means of opening hearts and paving a way to interethnic or intergroup competencies need for future public school teachers and educators (MCALLISTER; IRVINE, 2000). 
Figure 1. Hanuman painting in a Thai restaurant in Tucson, AZ. Hanuman is a main character in an ancient Hindu epic, Ramayana.

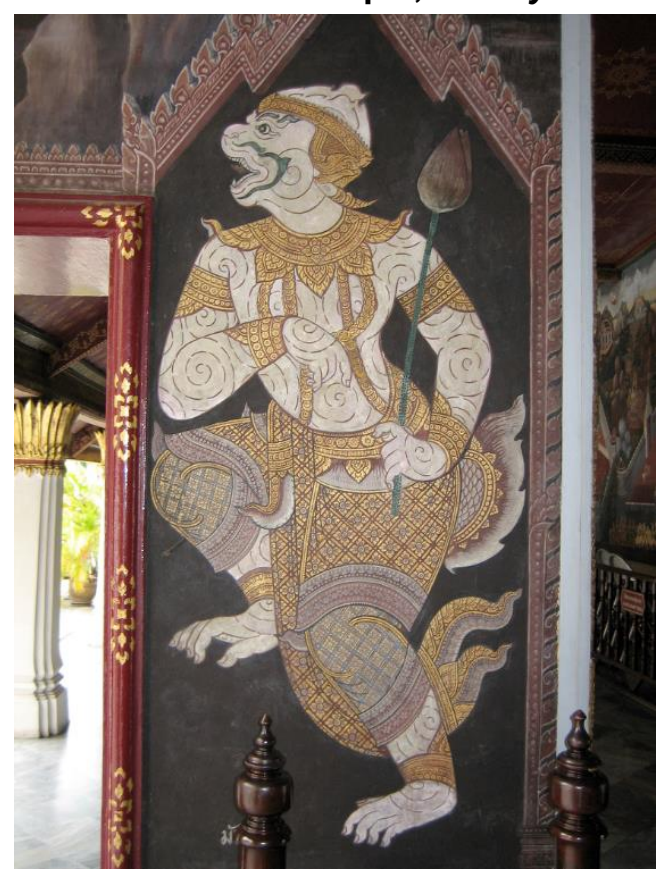

Source: Personal file.

\section{Challenging Cultural Stereotypes and Misconceptions}

Critical reflection and correction of stereotypical notions and misconceptions about other groups are important changes that social justice art education seeks to bring about in students' minds and hearts (BANKS, 2009; DESAI, 2009). Selfcorrective learning took place when students were confronted with their own misunderstandings and prejudices towards a particular ethnic group or culture. Some students shared first-hand testimonials of discriminatory stories and racial profanity used toward their informants. For example, a student researcher shocked the whole class by sharing a story of a second-generation Muslim student who told that when she was in Kindergarten, she was pushed into the sand on the playground by a boy who said that was where she belonged, after she wore her Muslim traditional dress for class show-and-tell. In this case, the student reporter as well as the class learned that discrimination and oppression were common experiences that took place at early ages in schools (BESWICK, 1990), questioning common assumption that "very young children are incapable of seriously understanding the implications of race and racism" (VAN AUSDALE; FEAGIN, 2001, p. 1). So, this helped the students see and value the importance of teaching about diversity issues in early school years, rather than 
avoiding or ignoring these issues as simply the case of "the unsophisticated, innocent child of many adult imaginations" (p. 1). As another example, while interviewing a Native American, a White student learned that in the workplace the Native American was treated as though she lacked intelligence due to the person's skin color and quiet disposition. The student was disturbed that skin color was criteria to evaluate people.

Another important lesson that was learned is that one must always be careful to avoid stereotypical assumptions towards people based upon physical complexion or skin color, and to be careful with labels when relating them to a particular ethnic group of people. This is especially true when you are ignorant of someone's cultural background and upbringing. Case in point, a White female art teacher in a Tucson local school, who was also a graduate student in my Diversity Issues class, decided to conduct research on Calaveras [skulls] and the Dia de los Muertos [Day of the Dead] for her class project. As she was new to Southwestern culture and had spent most of her life in Chicago, she just assumed that all her elementary students are were knowledgeable about Mexican cultural traditions and was surprised when many didn't know what a calavera was. The teacher also assumed that her two colleagues of seemingly Hispanic heritage knew about the Day of the Dead tradition when she selected them for interviewees. But she found out that they seemed to be offended by her assumption of knowledge. They said that their ancestors had lived in Mexico several generations ago, but they themselves did not possess any background experiences that made them innately knowledgeable about Calaveras and the Dia de los Muertos. The researcher learned a valuable lesson: that it is superficial and stereotypical to make assumptions connecting someone to the cultural origins of a particular ethnic group based on his/her name, skin color, or physical appearance.

\section{Self-Reflective Learning}

The lack of knowledge about ethnic groups beyond their own is noted in college education courses (BAKARI, 2003; PANG; SABLAN, 1998). For example, in Linda Thompson's class (1995), who taught a course at a Midwestern university focusing on the experiences of ethnic minority families, a white student admitted possessing no knowledge of the Hmongs, even though this immigrant ethnic group comprised a significant percentage of the local high school student body and urban population

SHIN, Ryan. Objeto étnico de pesquisa na comunidade para fomentar a aprendizagem interétnica. 456 Revista GEARTE, Porto Alegre, v. 5, n. 3, p. 449-460, set./dez. 2018.

Disponível em: http://seer.ufrgs.br/gearte 
where she grew up. Likewise, a white student in my class shared that knowing a person for less than a year in the university was very superficial because she had not known "the intimate aspects of her [informant's] life, her cultural background, or cultural identity . . . until this interview" (C. Reece, personal communication, October 15, 2009). In fact, she had not even thought to ask about such things before conducting this project.

Over the course of the diversity project, my students discovered how members of most minority groups, specifically recent immigrants (Asian, Indians or Middle Easterners) and Native Americans, value their culture and traditions. A white female student reported that a Malaysian mother is very "adamant about teaching her three daughters about her culture," and "celebrates important Malaysian holidays and cooks traditional Malaysian food." (D. Gold, October 14, 2009). As another example, when a Thangka artist (Thankga is a kind of Buddhist temple art form) was invited to my class by a student, he shared how much he appreciates the United States' students who are willing to hear about his Buddhist art. Another student shared that a Pysanka artist was eager to demonstrate Ukrainian Pysanka egg and decoration methods. My students recognized how much they value their heritage by their enthusiasm and their desire to bring the culture to the United States from their native country.

Figure 2. Tibetan prayer flags hanging in an antique bookstore in Tucson, Arizona.

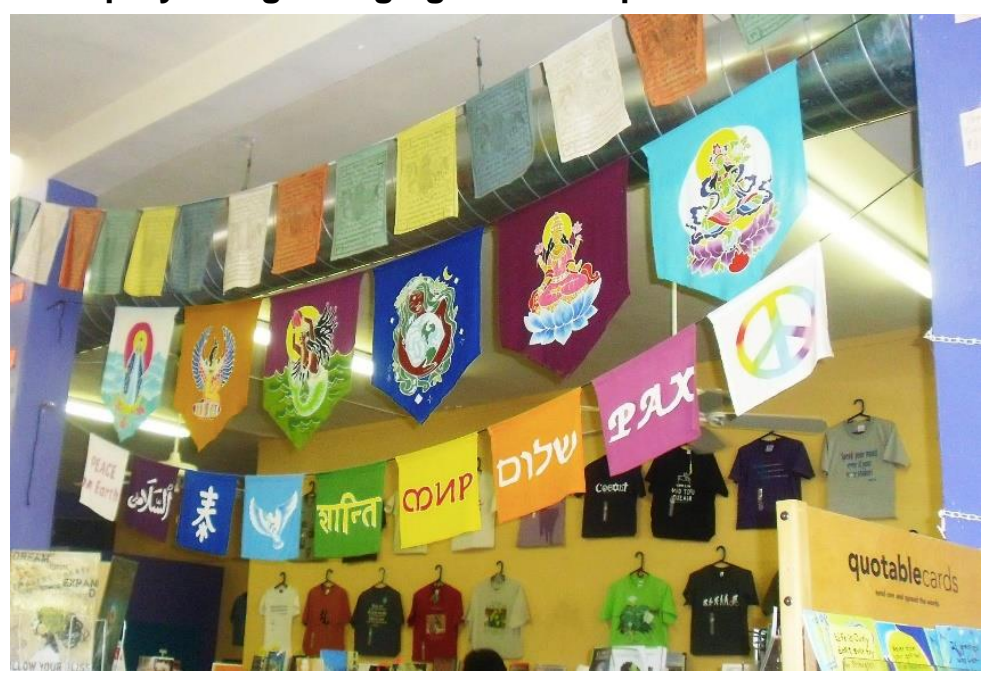

Source: Personal file.

Interestingly, my students are given an opportunity to learn about how they are perceived by people outside of U. S. in ways that contrasted sharply with their own 
views of themselves. A white student conducted this project by interviewing a twentyyear-old Guatemalan native male, via Skype surprised and shocked many of students in the class because Guatemalans would sum up the United States as being full of "opportunities," "expensive," and most shocking of all was to be seen as "fun!" as the "party city [sic]." Based on this Skype conversation, she was further led to believe that the majority of Guatemalan youths think that Americans are "all rich, marry for money, and never [have] to work" (C. Minton, personal communication, October 17, 2009). The student recognized that American movies and television programs were largely responsible for these assumptions. For example, the Guatemalan male she interviewed watched Real Housewives of Orange County.

\title{
Empathy
}

Although not extensive, students' knowledge and exposure to ethnic groups can lead to the development of empathy and caring for the studied groups. Most students who participated in the project developed empathetic acceptance of others. This was regularly witnessed in class through discussions, journal writings, student lamentations, sighs, compassionate expressions, voluntary offering of advice, and frequent outspoken determinations to apply their recently gained knowledge of cultural objects and art to their future classrooms. An example is found in the reflection paper of a Native American student who studied an Islamic object and interviewed a Muslim student:

\begin{abstract}
Part of what drew me to South Asian culture and Muslim [sic] was that I often think [they are] misinterpreted and misunderstood much like my Native American culture. Many people romanticize Native spirituality and culture because they only see the stereotypes... [M]any Americans and people around the world whether consciously or unconsciously believed that people of Muslim faith are terrorists... Similarly I noticed there were many elements of Zarah's explanation of her culture that seem to parallel my own. Her close-knit family, her high regard for tradition, and the pride of her heritage are all aspects of her personality that are culturally specific and I see in myself as well. (D. Jacobs-Morris, personal communication, October 20 , 2009)
\end{abstract}

Second-generation youths and adopted children are another story. Often they have been assimilated and mainstreamed into an American lifestyle. Young children and teenagers of immigrant parents appear to be influenced more strongly by American popular culture. For example, a student who conducted an interview with the two adopted Marshall Islands children showed their complete assimilation into 
American culture. The girls could not even recognize the traditional crafts and clothing of the Marshall Islands, and they were not even (remotely) interested in talking about their natural parents' culture. My students acknowledged that developing openmindedness and empathy toward others might be challenging, but also noted that it should be a chief responsibility of any educators (PHILLIPS, 2003; STOUT, 1999), an essential task in preparing their further students to look beyond their own ethnic backgrounds (BAKARI, 2003; PANG; SABLAN, 1998).

\section{Conclusion}

Students' responses to their community-based ethnic object research confirmed that interethnic communication and direct contact can help correct and dispel stereotypes and biases that they might have learned from early socialization. Through this project, students were engaged in dialogues and interaction with individuals and groups of people from different ethnic and cultural backgrounds in the community, which helped them break out of their own social comfort zones. They learned that communication with people from different ethnic backgrounds is an important first step in embracing others and their cultures. They also came to see the abundance of ethnic objects that exist in the community and that art teachers should consider when planning their teaching. This project also indicates the value of objects in promoting understanding of immigrant groups and their culture in the community. Despite the rhetoric and metaphors of current political climates, art educators should advocate and value these interethnic cultural exchanges among students and community members.

\section{References}

APPIAH, A. K. Cosmopolitanism: Ethics in a world of strangers. New York: W.W. Norton \& Co., 2006.

BAKARI, B. Preservice teachers' attitudes toward teaching African American students: Contemporary research. Urban Education, v. 38, p. 640-654, 2003.

BANKS, A. J. Teaching strategies for ethnic studies. Boston: Allyn and Bacon, 2009.

BESWICK, R. Racism in America's schools. (ERIC Digest n. 49). Eugene, OR: ERIC Clearinghouse on Educational Management. (ERIC Document Reproduction Service No. ED320196), 1990.

BOLIN, P.; BLANDY, D. Beyond visual culture: Seven statements of support for material culture studies in art education. Studies in Art Education, v. 44, n.3, p. 246-263, 2003.

BOURRIAUD, N. Relational aesthetics (trans. Simon Pleasance and Fronza Woods). Paris: Les Presses du Reel, 2002.

SHIN, Ryan. Objeto étnico de pesquisa na comunidade para fomentar a aprendizagem interétnica. 459 Revista GEARTE, Porto Alegre, v. 5, n. 3, p. 449-460, set./dez. 2018.

Disponível em: http://seer.ufrgs.br/gearte 
CHALMERS, F. G. Celebrating pluralism: Art, education and cultural diversity. Los Angeles: J. Paul Getty Trust Publications, 1996.

DESAI, D. Reflections on social justice art teacher education. In: ANDERSON, T.; D. GUSSAK, D.; HALLMARK, K. \& PAUL, A. (Eds.), Art Education for Social Justice. Reston, VA: National Art Education Association, 2010. p. 172-178.

GURIN, P.; DEY, E. L.; HURTADO, S.; GURIN, G. Diversity and higher education: Theory and impact on educational outcomes. Harvard Educational Review, v. 72, n. 3, p. 330-366, 2002.

HARRIS, M. History and significance of the emic/etic distinction. Annual Review of Anthropology, v. 5, p. 329-350,1976.

MCALLISTER, G.; IRVINE, J. J. Cross-cultural competency and multicultural teacher education. Review of Educational Research, v.70, n.1, p. 3-24, 2000.

PANG, V.; SABLAN, V. Teacher efficacy: How do teachers feel about their abilities to teach African American students? In M. Dilworth (Ed.), Being responsive to cultural differences: How teachers learn Thousand Oaks, CA: Corwin Press, 1998. p. 39-60.

PHILLIPS, L. C. Nurturing empathy. Art Education, v.56, n.4, p. 45-50, 2003.

PIKE, K. L. Language in relation to a unified theory of the structure of human behavior. The Hague: Mouton, 1967.

PRATT, M. L. Arts of the contact zone. Profession, v.91, p. 33-40, 1991.

RODENBORG, N.; HUYNH, N. On overcoming segregation: Social work and intergroup dialogue. Social Work with Groups, v.29, n.1, p. 27-44, 2006.

STOUT, C. J. The art of empathy: Teaching students to care. Art Education, v.52, n.2, p. 21-24, 33-34, 1999.

TATUM, B. D. Defining racism: 'Can we talk?' In: M. Adams, W. J. Blumenfeld, C. Castañeda, H. W. Hackman, M. L. Peters, \& X. Zúñiga (Eds.), Readings for diversity and social justice: An anthology on racism, antisemitism, sexism, heterosexism, ableism, and classism. New York: Routledge, 2000. p. 7982.

THOMPSON, L. Teaching about ethnic minority families using a pedagogy of care. Family Relations, $v$. 44, n. 2, p. 129-135, 1995.

VAN AUSDALE, D.; FEAGIN, J. The first $R$ : How children learn race and racism. Lanham, MD: Rowman \& Littlefield, 2001.

WEJSA S. \& LESSER, J. Migration in Brazil: The Making of a Multicultural Society. Migration Policy Institute, 2018. Retrieved from https://www.migrationpolicy.org/article/migration-brazil-makingmulticultural-society. Access: 29 March 2018.

WITCOMB, A. Using souvenirs to rethink how we tell histories of migration: some thoughts. In S. H. Dudley, A. J. Barnes, J. Binnie, J. Petrov, and J. Walklate (Eds.), Narrating objects, collecting stories. Abingdon, England: Routledge, 2012. p. 36-50.

\section{Ryan Shin}

Associated Professor of Art and Visual Education at the University of Arizona. PhD in Art Education by the Florida State University. His research deals with critical discourse about visual culture of the minority, representation and image appropriation and Asian objects in popular media and in visual culture.

Email: shin@email.arizona.edu

Currículo: https://www.linkedin.com/in/ryan-shin-08347933

Recebido em 2 de novembro de 2018 Aceito em 5 de dezembro de 2018 